\title{
PENINGKATAN TOP OF MIND MELALUI FREKUENSI PENAYANGAN, DAYA TARIK PESAN DAN WAKTU PENAYANGAN IKLAN
}

\author{
Gilang Puspita Rini
}

Dosen Jurusan Manajemen, Fakultas Ekonomi dan Bisnis, Universitas Muria

Kudus

e-mail: gilang.puspita@umk.ac.id

\begin{abstract}
ABSTRAK
Promosi dapat dilakukan dengan berbagai cara, diantaranya yaitu melalui periklanan. Perusahaan harus benar-benar dapat mengalokasikan anggaran promosi dan membaginya dengan tepat untuk berbagai alat promosi. Salah satunya adalah mengalokasikan anggaran untuk periklanan. Terdapat beberapa pilihan media yang dapat digunakan untuk beriklan, salah satunya adalah media televisi. Salah satu tujuan perusahaan melakukan kegiatan periklanan adalah untuk meningkatkan top of mind merek produknya. Dalam penelitian ini dibahas beberapa faktor yang dapat mempengaruhi top of mind merek shampo Pantene, yaitu frekuensi penayangan iklan, daya tarik pesan iklan dan waktu penayangan iklan. Tujuan dari penelitian ini adalah untuk menganalisis faktor-faktor yang mempengaruhi top of mind merek shampo Pantene melalui media televisi oleh PT Unilever Tbk. Setelah dilakukan telaah pustaka, penyusunan hipotesis, pengumpulan data melalui penyebaran terhadap 77 (tujuh puluh tujuh) orang responden dengan teknik random sampling, kemudian dilakukan analisis terhadap data yang diperoleh dengan menggunakan regresi linier berganda, maka hasil penelitiannya adalah ketiga variabel yang diujikan, yaitu frekuensi penayangan iklan, daya tarik pesan, dan waktu penayangan iklan berpengaruh positif terhadap variabel dependennya yaitu top of mind merek shampo sunsilk.
\end{abstract}

Kata Kunci: top of mind, brand awareness, pesan iklan, frekuensi iklan, media televisi

\section{ABSTRACT}

Promotion can be done in various ways, includes advertising. Companies should really be able to allocate a promotional budgets and share them appropriately for various promotional tools. For example is to allocate a budget for advertising. There are several media options that can be used to advertise, one of the option is the television media. One of the company's goals for advertising is to improve the top of mind of its product brand. This study is discussed several factors that can 
affect the top of mind of brand "Pantene" shampoo, involved frequency of ad delivering, the attractiveness of advertising messages and time of advertising. The purpose of this study is to analyze the factors that affect the top of mind brand shampoo Pantene through television media by PT Unilever Tbk. After the literature review, hypothesis preparation, data collection through the dissemination of 77 (seventy seven) respondents with random sampling technique, then the data obtained is analyzed by using multiple linear regression, the results of the research are those three variables tested, frequency ad delivering, message appeal, and advertising time have a positive effect on the dependent variable that is top of mind of brand "pantene" shampoo.

Keywords: top of mind, brand awareness, ad messages, ad frequency, television media

\section{PENDAHULUAN}

Kegiatan promosi banyak dilakukan oleh perusahaan untuk memberikan informasi mengenai produk dan pelayanan perusahaan. Promosi juga dapat menjadi salah satu strategi yang digunakan perusahaan untuk membuat produknya dikenal, diingat, dan lekat di benak konsumen.

Salah satu media promosi yang masih menjadi pilihan adalah media televisi. Penggunaan media televisi untuk mengiklankan suatu produk banyak digunakan oleh perusahaan karena menggabungkan gambar, suara, dan gerak, memiliki atensi tinggi, tingkat reach tinggi (reach adalah prosentase orang dalam pasar sasaran yang terekspos dengan sebuah kampanye iklan selama periode waktu tertentu), coverage luas dan prestise (Tjiptono, 2006)

Shampo merupakan salah satu produk yang tingkat persaingannya cukup tinggi. Tingkat perpindahan merek dari shampo satu ke shampo yang lain juga cukup tinggi. Kondisi ini memaksa perusahaan untuk mengeluarkan biaya iklan yang tidak sedikit. Dari biaya iklan yang besar tersebut, perusahaan harus dapat memanfaatkannya dengan baik. Salah satu tujuan PT Unilever Tbk mengiklankan produk shampo merek Pantene adalah untuk meningkatkan brand awareness merek shampoo Pantene sampai pada level top of mind. Dalam kurun waktu 2012 hingga 2018 terjadi penurunan top of mind merek shampo Pantene, seperti ditunjukkan dalam tabel 1 berikut ini:

Tabel 1. Data Top of mind Shampo Pantene

\begin{tabular}{|c|c|}
\hline TAHUN & TOP OF MIND \\
\hline 2012 & $29,2 \%$ \\
\hline
\end{tabular}




\begin{tabular}{|c|c|}
\hline 2013 & $27,3 \%$ \\
\hline 2014 & $25,1 \%$ \\
\hline 2015 & $21,4 \%$ \\
\hline 2016 & $22,0 \%$ \\
\hline 2017 & $22,6 \%$ \\
\hline 2018 & $24,1 \%$ \\
\hline
\end{tabular}

Sumber: Majalah Marketing, 2018

Top of mind adalah tingkat kesadaran merek di mana jika seseorang konsumen yang ditanya secara langsung tanpa diberi bantuan pengingatan, maka merek yang paling banyak disebut pertama kali adalah merek dengan top of mind tinggi (Aaker, 1996). Dalam usaha meningkatkan top of mind salah satunya dibutuhkan iklan yang efektif. Efektivitas iklan bergantung pada banyak faktor, salah satunya adalah perencanaan media. Dalam perencanaan media itu sendiri, perlu direncanakan secara mendalam terkait frekuensi penayangan iklan, daya tarik pesan, waktu penayangan iklan, sehingga diperoleh iklan yang efektif.

Berdasarkan uraian di atas, maka rumusan masalah dalam penelitian ini adalah "Apakah frekuensi penayangan iklan, daya tarik pesan, dan waktu penayangan iklan dapat meningkatkan top of mind merek shampo Pantene?”.

\section{TINJAUAN PUSTAKA}

\section{Iklan}

Iklan didefinisiakn sebagai segala bentuk penyajian dan promosi ide, barang atau jasa secara nonpersonal oleh suatu sponsor tertentu yang memerlukan pembayaran (Kotler, 2005). Perusahaan menggunakan iklan sebagai strategi memperkenalkan produk atau jasa yang baru diluncurkan oleh perusahaan. Iklan dapat juga digunakan oleh perusahaan untuk memaparkan promosi ide sehingga gagasan yang dikemukakan oleh perusahaan dapat tersampaikan kepada konsumen. Dalam beriklan, perusahaan membiayai seluruh biaya yang timbul akibat adanya aktivitas peiklanan. Terkait dengan besarnya biaya iklan yang timbul, maka perusahaan harus dapat menentukan tujuan dilakukannya program periklanan. Salah satu tujuan iklan adalah untuk menjaga agar merek perusahaan tetap segar dalam ingatan konsumen.

Dengan adanya tujuan periklanan yang jelas, keefektivan suatu iklan dapat diukur dengan lebih mudah. Selain itu, dengan adanya tujuan yang jelas, perusahaan dapat melakukan evaluasi apakah tujuan awal perusahaan untuk beriklan sudah tercapai. 
Pemilihan media juga merupakan hal yang perlu diperhatikan dalam strategi iklan. Salah satu media yang saat ini masih paling banyak digunakan untuk beriklan adalah media televisi. Sebagai media periklanan, keunikan televisi adalah dapat mendemonstrasikan pesan, suara, dan gerak yang ingin disampaikan kepada konsumen, namun juga mahal karena keunikan tersebut.

\section{Kesadaran Merek}

Kesadaran (awareness) menggambarkan keberadaan merek didalam pikiran konsumen yang dpaat menjadi penentu dalam beberapa kategori dna biasanya mempunyai peranan kunci dalam pembentukan brand equity (Aaker, 1996). Kesadaran merek dapat memengaruhi proses pengambilan keputusan pembelian melalui persepsi dan tingkah laku konsumen. Jika kesadaran mereknya rendah, maka dalam proses pengambilan keputusan pembeliannya, konsumen tidak mengingat merek dalam kategori produk tertentu.

Terdapat beberapa tingkatan kesadaran merek (brand awareness) dari tingkat terendah sampai tingkat tertinggi (Aaker 1996), yaitu dari unaware brand (tidak menyadari merek), brand recognition (Pengenalan merek), brand recall (pengingatan kembali) sampai dengan top of mind (puncak pikiran). Tujuan perusahaan meningkatkan kesadaran merek yaitu untuk menjadikan mereknya menjadi top of mind pada kategori produk tertentu.

\section{Top of mind}

Situasi dimana merek sudah dikenal luas oleh konsumen dan menempati urutan pertama yang disebutkan konsumen pada saat mengingat nama merek dari kategori produk tertentu,didalam istilah pemasaran dikenal dengan tingkat awareness brand yang sudah ada pada level top of mind. Istilah top of mind dikenal dengan tingkat kesadaran merek dimana jika seseorang konsumen yang ditanya secara langsung tanpa diberi bantuan pengingat, maka merek yang paling banyak disebut pertama kali adalah merek dengan top of mind tinggi (Aaker,1996).

Dalam konsep brainware management (Bahaudin, 2000) dapat dipahami bahwa perusahaan yang mereknya ada pada level top of mind adalah perusahaan yang secara sistematik mampu melakukan penyimpanan informasi nilai kepercayaan pelanggan serta diferensiasi paroduk sebagai memori emosional yang kuat dalam system libic otak manusia. Sehingga perusahaan tersebut harus mampu membuat konsumen menyimpan informasi tentang kepercayaan pelanggan dan karakteristik produk perusahaan kedalam system limbic otak manusia sebagai memori emosional.

Fenomena dampak top of mind dalam memengaruhi proses pembelian oleh konsumen perlu dipahami berdasarkan cara kerja otak manusia. Pemahaman 
terhadap cara kerja otak manusia dapat menjadi dasar logika untuk pengembangan program pembentukan top of mind secara efektif. Pada dasarnya otak manusia dapat dibagi menjadi dua bagian, yaitu otak rasional dan otak emosional. Otak rasional disebut dengan neocortex, sedangkan otak emosional disebut dengan sistem limbic (Rudito, 2007).

System limbic, dimana didalamnya terdapat amgydala, berfungsi sebagai penyimpan memori dan pengendali emosi. Pada system limbic inilah dipusatkan pengaturan emosi seperti senang, kesal, ataupun loyalitas terhadap suatu merek. Kekuatan top of mind maksimal pada saat konsumen dihadapkan pada keharusan untuk memutuskan pembelian. Pada tahap ini proses berfikir rasional menjadi kurang dominan, sehingga sistem limbic sebagai pengendali otak emosional memegang kendali atas respon akhir konsumen. Kendali perilaku konsumen didominasi oleh amgydala yang merupakan bagian dari sistem limbic. Pada situasi amgydala aktif atau dominan memegang kendali, maka yang terjadi adalah suatu mekanisme kerja otak yang kerap dikenal dengan cara kerja otak bawah sadar.

Pemasar yang mampu melakukan aktivasi amgydala secara efektif, maka dia akan mudah meningkatkan top of mind mereknya. Aktivasi ini dapat ditempuh dengan cara mengembangkan keunggulan produk atau jasa sehingga menjadi produk yang berbeda dari produk pesaing. Jika produk memiliki ciri yang mudah diingat, maka produk atau jasa perusahaan perusahaan akan terhubung dengan baik secara emosional dengan mindset yang tersimpan dalam limbic konsumen.

Untuk membuat konsumen ingat akan produk perusahaan, salah satunya adalah dengan periklanan. Periklanan akan membuat konsumen sadar (aware) terhadap merek dalam kategori produk atau jasa tertentu. Dalam beriklan harus pula diperhatikan tentang frekuensi penayangan iklan, dyaa tarik pesan iklan, serta waktu penayangan ikan yang sesuai, sehingga risiko kegagalan program periklanan tidak terjadi, seperti misalnya perusahaan sudah mengeluarkan biaya mahal untuk beriklan, tetapi ternyata iklannya tidak efektif hanya karena kesalahan dalam pengambilan keputusan tentang frekuensi, pesan, dan waktu penayangan iklan.

\section{Frekuensi penayangan iklan dan top of mind}

Terdapat beberapa definisi terkait dengan frekuensi. Dalam bukunya,(Shimp, 2003), frekuensi merupakan jumlah waktu secara rata-rata dalam periode empat minggu dimana para audiens sasaran diekspos pada suatu media tertentu dalam bentuk aktivitas melihat, membaca atau mendengar yang termasuk dalam jadwal media tertentu. Sementara Kotler (2005), menyebutkan bahwa frekuensi merupakan jumlah waktu dalam kurun waktu tertentu ketika orang atau keluarga rata-rata terpapar pada pesan tersebut. Kedua pendapat 
tersebut berbeda pada penekanannya. Jika Kotler penekanannya pada pesan, maka Shimp lebih lebih kepada iklan secara keseluruhan.

Karena jenis iklan hanya bertahan sebentar dan karena sering kali hanya bagian kecil dari suatu iklan yang dipersepsikan oleh konsumen pada suatu waktu tertentu, para pemasang iklan mengulangi iklan mereka hingga konsumen akan mengingat pesan tersebut. Pengulangan iklan dianggap merupakan teknik yang paling ampuh untuk melekatkan pesan di benak konsumen. Pengulangan pesan suatu iklan merupakan suatu strategi untuk mendekati khalayak sasaran.

Pengulangan iklan meliputi tiga dimensi (Simamora, 2003) yaitu: pertama, intensitas tayang, yaitu frekuensi penayangan iklan, kedua ketepatan waktu tayang, dan yang ketiga adalah durasi ikan yaitu lama waktu penayangan iklan. Mengandalkan pesan pada pengulangan dapat menjadi sangat diperlukan dalam beberapa kondisi. Ketika komunikasi dengan konsumen membawa seperangkat informasi yang besar, konsumen mungkin tidak dapat langsung memahami sepenuhnya terhadap pesan yang disampaikan dalaam satu kali pemaparan, walaupun hal ini bergantung pada jenis media dimana iklan tersebut disampaikan kepada audiens misalnya media televisi, yang durasi iklannya sebentar dan dibutuhkan lebih dari satu kali pemaparan kepada audiens, berbeda dengan periklanan luar ruang yang durasi ikannya dapat dilihat konsumen lebih lama.

Pengulangan iklan akan lebih berguna bagi beberapa kategori produk daripada kategori produk lain (Indriyani dan Ihlaw, 2002). Misalnya, iklan produk mobil lebih membutuhkan pengulangan daripada produk makanan. Hal tersebut terjadi karena apabila konsumen membeli makanan hanya menimbulkan tingkat ketelibatan yang rendah, sementara untuk produk mobil diperlukan keterlibatan yang tinggi sebelum proses pengambilan keputusan. Seperti halnya mobil, shampo juga menimbulkan tingkat keterlibatan yang tinggi. Shampo, sebagai produk kosmetik tidak bisa sembarang digunkan oleh konsumen. Karena itu, dalam proses pengambilan keputusan pembelian shampo, konsumen umumnya mengumpulkan informasi sebanyak-banyaknya untuk menemukan shampo ynag cocok digunakan. Untuk alasan tersebut, pengulangan iklan harus dilakukan perusahaan agar dapat memenuhi kebutuhan konsumen akan informasi. Untuk itu, pengulangan iklan adalah alat yang penting untuk meningkatkan pembelajaran pesan.

Pembelajaran pesan akan tumbuh dengan tambahan pemaparan walaupun dengan kecepatan yang berkurang, yaitu tiap pemaparan berikutnya menambah lebih sedikit disbanding pemaparan sebelumnya (Engel et al., 1995). Konsumen tidak langsung dapat menyerap informasi pada sekali penayangan. Jadi penayangan berikutnya menambah informasi lebih sedikit dari penayangan pertama. Tetapi pengulangan tetap berfungsi untuk menambah informasi yang sudah tertanam di benak konsumen. 
Berdasarkan uraian di atas, dapat diambil suatu hipotesis yang mewakili hubungan antara frekuensi penayangan iklan dengan top of mind, yaitu sebagai berikut : H1 = Frekuensi penayangan iklan mempunyai pengaruuh positif terhadap top of mind sehingga semakin tinggi frekuensi penayangan iklan, maka semakin tinggi top of mind.

\section{Daya tarik pesan dan top of mind}

Pesan bisa berupa ide, pikiran, sikap, citra atau informasi lain yang ingin diekspresikan oleh si pengirim pesan kepada audiens yang dituju (Ristiyani dan Ihlaw, 2005). Ada empat hal yang harus diperhatikan dalam merumuskan pesan periklanan (Kotler, 2005) yaitu, pertama adalah isi pesan.Ada tiga jenis daya tarik isi pesan yaitu, (a) daya tarik rasional,(b) daya tarik emosional,dan (c) daya tarik moral. Yang kedua adalah struktur pesan, ketiga adalah format pesan, dan ynag keempat adalah sumber pesan.

Daya tarik rasional menyatakan bahwa produk yang diiklankan akan menghasilkan manfaat bagi penggunanya. Iklan dibuat dengan isi pesan yang menggambarkan manfaat apabila konsumen mengonsumsi produk yang diiklankan. Misalnya adalah pesan yang menunjukkan mutu produk, mislanya iklan yang berisi produk yang diiklankan bermutu tinggi seperti iklan kulkas yang awet

Daya tarik isi pesan yang kedua yaitu daya tarik emosional, bisa berupa daya tarik emosional positif, bisa juga negative. Contoh daya tarik emosional misalnya memanfaatkan rasa bersalah, ketakutan, dan rasa malu konsumen. Sedangkan daya tarik emosional positif biasanya menggunakan humor, cinta, dan kebahagiaan.Daya tarik moral biasanya digunakan untuk mendorong orang mendukung masalah-masalah sosial, seperti lingkungan hidup yang lebih bersih dan sehat atau himbauan lain yang bersifat sosial. Iklan yang disampaikan oleh perusahaan atau organisasi nirlaba banyak memanfaatkan daya tarik moral dalam kampanyenya.

Ada berbagai cara untuk membuat pesan dalam suatu periklanan mudah dihafalkan oleh konsumen (Ristiyanti dan Ihlaw, 2005) antara lain: Pertama , penyampaian pesan dilakukan melalui humor, kedua berikan alasan pada audiens mengapa audiens harus mendengarkan pesan pada iklan tersebut, ketiga gunakan pertanyaan untuk menimbulkan keterlibatan dengan audiens, keempat siarkan pesan dengan istilah yang dikenal baik oleh audiens dan ciptakan pesan berdasarkan minat audiens.

Dari uraian di atas dapat ditarik suatu hipotesis yang mewakili hubungan antara daya tarik pesan dengan top of mind, yaitu sebagai berikut :

$\mathrm{H} 2$ = Daya tarik pesan mempunyai pengaruh positif terhadpa top of mind sehingga semakin tinggi daya tarik pesan, maka semakin tinggi top of mind. 


\section{Waktu penayangan ikan dan top of mind}

Menurut pendapat Shimp (2003), biaya periklanan, karakteristik khalayak dan kesesuaian pemrograman, snagat bervariasi pada jam-jam tertentu di suatu hari dan hari-hari tertentu di suatu minggu. Sehingga dalam suatu harinya, biaya periklanan, karakteristik audiens dan kesesuaian pemrograman dapat berbedabeda. Misalnya, biaya periklanan di waktu siang dan waktu malam bisa berbeda tarifnya, begitu pula dengan karakteristik audiensnya yang menonton televisi di malam hari dengan yang di siang hari pasti berbeda karakteristiknya.

Kesesuaian waktu penayangan iklan dapat mempengaruhi frekuensi seberapa sering khalayak sasaran melihat iklan produk dan atau jasa tertentu. Walaupun dengan frekuensi tinggi, tetapi apabila waktu penayangan tidak sesuai dengan waktu dimana audiens sasaran menonton televisi, maka penayangan iklan tersebut sia-sia. Perusahaan harus dapat melakukan positioning untuk produknya serta menentukan audiens sasarannya, kemudian setelah itu bisa ditentukan waktu yang sesuai untuk mengiklankan produk atau jasa perusahaan tersebut. Karena keputusan mengenai waktu penayangan iklan berhubungan erat dengan biaya yang besar, maka perusahaan harus dapat memanfaatkan budget yang dimikinya guna menyampaikan pesan kepada audiens secara efektif.

Apabila waktu penayangan iklan sesuai dengan waktu audiens menonton televisi, maka kemungkinan audiens sasaran melihat iklan produk atau jasa perusahaan semakin tinggi. Misalnya iklan shampo yang ditujukan untuk para wanita ditayangkan pada saat sinetron tayang, sehingga audiens sasaran dapat melihat iklan shampo tersebut. Dengan demikian diharapkan audiens sasaran dapat mengingat iklan yang ditayangkan yang pada akhirnya akan menimbulkan top of mind terhadap produk atau jasa perusahaan di benak konsumen.

Dengan demikian dapat diambil suatu hipotesis yang mewakili hubungan antara waktu penayangan iklan dengan top of mind, yaitu sebagai berikut :

$\mathrm{H} 3$ = Waktu penayangan iklan mempunyai pengaruh positif terhadap top of mind sehingga semakin tepat waktu penayangan iklan, maka semakin tinggi top of mind

\section{Gambar 1. Kerangka Pikir}

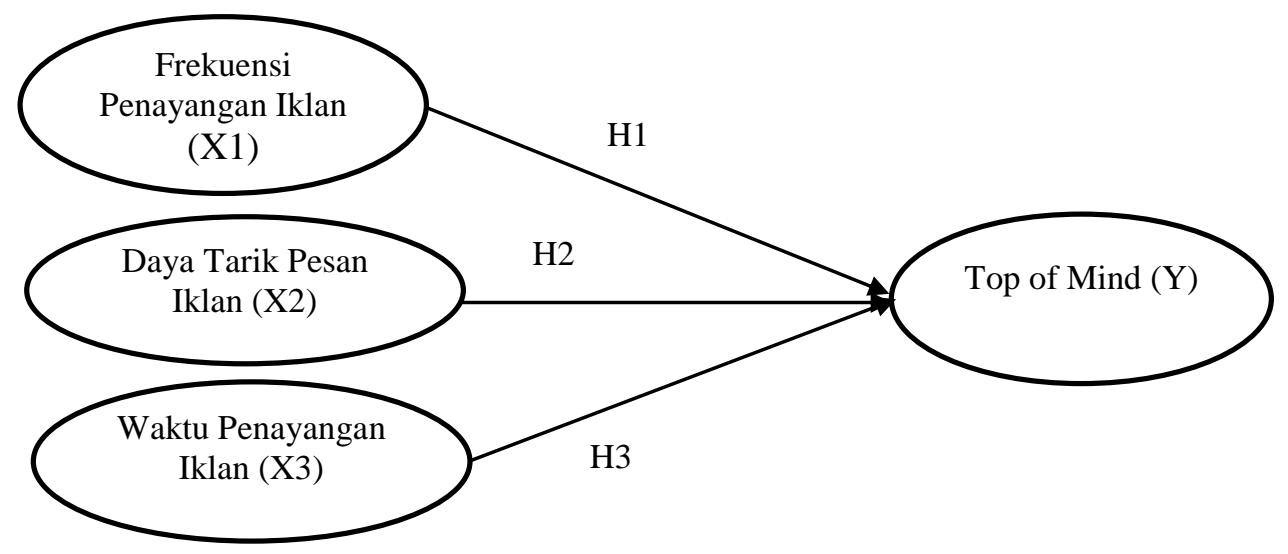




\section{METODE PENELITIAN}

Populasi dalam penelitian ini adalah Mahasiswa Fakutas Ekonomi dan Bisnis Universitas Muria Kudus Program S1 angkatan 2017 jurusan Manajemen kelas $\mathrm{C}$ sampai $\mathrm{G}$ berjumlah 327 mahasiswa. Teknik pengambilan sampel dalam penelitian ini menggunakan probability sampling dengan pendekatan random sampling. Pengambilan sampel secara random atau acak dilakukan dengan undian. Penentuan jumlah sampel dilakukan dengan menggunakan rumus solvin dengan jumlah minimal adalah 77 responden.

Data yang digunakan dalam penelitian ini adalah data primer. Data tersebut dikumpulkan dengan menggunakan instrumen kuesioner. Hasil kuesioner dianalisis menggunakan analisis regresi linier berganda. Data yang diperoleh dalam penelitian ini akan diolah menggunakan software SPSS. Analisis kuantitatif yang dilakukan dalam penelitian ini yang pertama adalah uji kualitas data meliputi uji reliabilitas, dan uji validitas, yang kedua yaitu uji asumsi klasik yaitu uji multikolinieritas, uji heteroskedatsisitas, uji normalitas, dan yang ketiga adalah pengujian hipotesis. Secara statistik, ketepatan fungsi regresi sampel dalam menaksir nilai actual, dpaat diniai dengan Goodness of Fit nya yaitu keofisien determinasi $\left(\mathrm{R}^{2}\right)$, nilai statistik $\mathrm{f}$ dan nilai statistik t (Ghozali, 2005).

\section{HASIL DAN PEMBAHASAN}

Setelah dilakukan pengumpulan data dan analisis data menggunakan software SPSS, maka diperoleh hasil uji yang pertama yaitu reliabilitas, nilai Alpha dari tiap variabel menunjukkan angka lebih besar dari 0,6. Sehingga dapat dikatakan variabel variabel yang diuji adalah reliabel uji yang kedua yaitu uji validitas. Dalam penelitian ini uji validitas dilakukan dengan melakukan korelasi antara masing-masing skor indikator dengan total skor konstruk. Dari hasil output SPSS, terlihat bahwa korelasi antara masing-masing indikator dengan variabelnya menunjukkan hasil yang signifikan, sehingga dapat dikatakan bahwa masingmasing indikator pertanyaan adalah valid.

Dalam uji asumsi klasik, terdapat tiga pengujian yaitu uji multikolinieritas, uji heterokedastisitas, dan uji normalitas. Dalam uji multikolonieritas, hasil perhitungan nilai tolerance menunjukkan tidak ada variabel independen yang memiliki tolerance kurang dari 0,1 yang berarti tidak ada korelasi antar variabel independen. Hasil perhitungan nilai Variance Inflation Factor (VIF) juga menunjukkan hal yang sama, yaitu tidak ada satu variabel independen yang memiliki VIF lebih dari 10. Sehingga dapat diinterpretasikan bahwa tidak ada multikolinieritas antar variabel independen dengan model regresi. Uji asumsi klasik yang kedua yaitu uji heterokedastisitas, dari hasil grafik scatterplot dapat diketahui bahwa tidak ada pola yang jelas serta titik-titik menyebar di atas dan di bawah angka 0 (nol) pada sumbu Y. Uji yang ketiga 
adalah uji normalitas, dalam hasil grafik normal probability plot, didapatkan data menyebar di sekitas garis diagonal dan mengikuti arah garis diagonal, sehingga dapat di jelaskan bahwa model regresi memenuhi asumsi normalitas.

Dari hasil uji regresi liniear berganda, dapat diperoleh persamaan regresinya. Menurut hasil pengujian menggunakan SPSS diperoleh tabel 1.1 seperti berikut.

Tabel 2. Hasil Uji Regresi Liniear Berganda

Coefficients $^{\text {a }}$

\begin{tabular}{|c|c|c|c|c|c|c|c|}
\hline \multirow[b]{2}{*}{ Model } & \multicolumn{2}{|c|}{$\begin{array}{c}\text { Unstandardized } \\
\text { Coefficients }\end{array}$} & \multirow{2}{*}{$\begin{array}{l}\begin{array}{l}\text { Standardized } \\
\text { Coefficients }\end{array} \\
\text { Beta }\end{array}$} & & \multirow[b]{2}{*}{ Sig. } & \multicolumn{2}{|c|}{$\begin{array}{c}\text { Collinearity } \\
\text { Statistics }\end{array}$} \\
\hline & B & Std. Error & & & & Tolerance & VIF \\
\hline 1 (Constant & ,062 & 1,732 & & ,036 & ,972 & & \\
\hline $\mathrm{X} 1$ & , 194 & ,086 & ,202 & 2,249 &, 028 & ,610 & 1,638 \\
\hline $\mathrm{X} 2$ & , 188 & ,086 & , 197 & 2,180 & ,033 & ,605 & 1,654 \\
\hline X3 & ,627 & ,102 &, 537 & 6,154 &, 000 & ,648 & 1,542 \\
\hline
\end{tabular}

a. Dependent Variable: Y

Sumber: Data Primer yang diolah, 2018

Dari tabel 2 tersebut, persamaan regresi yang diperoleh adalah sebagai berikut:

$\mathrm{Y}=0,202 \mathrm{X} 1+0,197 \mathrm{X} 2+0,537 \mathrm{X} 3$

Keterangan:

$\mathrm{Y}=$ Top of mind

$\mathrm{X} 1$ = Frekuensi Penayangan Iklan

$\mathrm{X} 2$ = Daya Tarik Pesan

X3 = Waktu Penayangan Iklan

Persamaan regresi berganda di atas adalah: variabel frekuensi penayangan iklan (X1) berpengaruh positif terhadap top of mind dengan nilai 0,202. Variabel daya tarik pesan (X2) berpengaruh positif terhadap top of mind yaitu nilainya 0,197 . Sama halnya dengan frekuensi penayangan iklan dan daya tarik pesan, variabel waktu penayangan iklan (X3) juga berpengaruh positif terhadap top of mind dengan nilai sebesar 0,537.

Ketepatan fungsi regresi sampel dalam menaksir nilai aktual dapat dinilai dengan goodness of fit nya. Secara statistik setidaknya hal ini dapat diukur dari koefisien determinasi $\left(R^{2}\right)$, nilai statistik $\mathrm{F}$ dan nilai statistik t. Dalam hasil pengujian, diperoleh nilai adjusted $\mathrm{R}$ Square sebesar 0,624 artinya kemampuan variabel-variabel independen menjelaskan besarnya variabilitas variabel dependen adalah sebesar $62,4 \%$, sedangkan sisanya $(100 \%-62,4 \%=37,6 \%)$ dijelaskan oleh 
variabel - variabel independen lain diluar variabel frekuensi penayangan iklan, daya tarik pesan dan waktu penayangan iklan.Untuk hasil uji F, berdasarkan hasil pengujian diperoleh nilai $\mathrm{F}$ sebesar 43.086 pada tingkat signifikansi $0 \%$ yang dapat dimaknai bahwa semua variabel independen yang digunakan dalam model secara bersama-sama dapat menjelaskan variabel dependennya. Pengujian selanjutnya adalah uji $\mathrm{t}$, hasil pengujian uji $\mathrm{t}$ menunjukkan bahwa variabel frekuensi penayangan iklan (X1) mempunyai tingkat signifikansi 0,028, kemudian variabel daya tarik pesan (X2) mempunyai signifikansi 0,033 dan variabel waktu penayangan iklan (X3) memiliki tingkat signifikasni 0,00. Dari ketiganya, diperoleh nilai kurang dari 0,05. sehingga dapat diinterpretasikan bahwa ketiga variabel independen secara individual masing-masing mempengaruhi variabel $\mathrm{Y}$ nya yaitu top of mind.

\section{PENUTUP}

\section{Kesimpulan}

Penelitian ini secara khusus menguji pengaruh faktor frekuensi penayangan, daya tarik pesan dan waktu penayangan iklan terhadap top of mind merek shampo Pantene. Tujuan penelitian ini adalah untuk menganalisis pengaruh frekuensi penayangan iklan, daya tarik pesan dan waktu penayangan ilkan melalui media televisi oleh PT Unilever Indonesia, Tbk dalam mepengaruhi top of mind merek shampo Pantene.

Setelah dilakukan telaah pustaka dan penyusunan hipotesis, data dikumpulkan melalui penyebaran kuesioner terhadap 77 orang mahasiswa Fakultas Ekonomi dan Bisnis Universitas Muria Kudus dengan menggunakan teknik random sampling kemudian dilakukan analisis terhadap data yang diperoleh dengan menggunakan analisis data secara kuantitatif dan kualitatif. Dalam analisis kuantitatif, pengujian validitas dan reliabilitas dilakukan terlebih dahulu, kemudian uji asumsi klasik yang meliputi uji multikolinearitas, uji heterokedastisitas dan uji normalitas, setelah itu dilakukan analisis regresi berganda, dan yang terakhir dilakukan uji hipotesis yang meliputi uji $\mathrm{F}$, uji $\mathrm{t}$ dan analisis koefisien determinasi $\left(\mathrm{R}^{2}\right)$. Analisis kualitatif merupakan interpretasi dari data-data yang diperoleh dalam penelitian serta hasil pengolahan data yang sudah dilaksanakan dengan memberi keterangan dan penjelasan.

Berdasarkan hasil analisa data dengan menggunakan regresi liniear berganda, sebagiamana dijelaskan sebelumnya bahwa ada pengaruh anatara frekuensi penayangan iklan, daya tarik pesan dan waktu penayangan iklan 
terhadap top of mind merek shampo Pantene. Maka berikut ini adalah kesimpulan dari masinh-masing hipotesis:

H1: Frekuensi penayangan iklan mempunyai pengaruh positif terhadap top of mind sehingga semakin tinggi frekuensi penayangan iklan, maka semakin tinggi top of mind.

Kotler (2005) menyatakan bahwa kesadaran audiens akan makin besar apabila makin tinggi frekuensi, pengaruh positif ini tampak pada pernyataan responden. Ketika sebuah iklan diulang beberapa kali, maka audiens akan semakin hafal dengan iklan tersebut dan informasi yang diterima dari iklan tersebut juga bertambah seiring dengan semakin banyaknya pengulangan iklan di media terutama dalam hal ini adalah media televisi.

$\mathrm{H} 2$ : daya tarik pesan mempunyai pengaruh positif terhadap top of mind sehingga semakin tinggi daya tarik pesan, maka semakin tinggi top of mind.

Daya tarik memiliki peranan sangat penting agar mampu menarik minat konsumen untuk melihat dan membaca iklan tersebut. Daya tarik iklan harus memiliki karakteristik dimana periklanan harus menunjukkan manfaat yang membuat produk menarik bagi para konsumen, daya tarik harus terpercaya dimana produk atau jasa tersebut akan menghantarkan manfaat yang dijanjikan, daya tarik harus berbeda dimana daya tarik tersebut harus bisa menjelaskan bahwa produk itu lebih baik daripada merek pesaing (Kotler \& Armstrong, 2006). Diingatknya suatu pesan iklan karena daya tariknya merupakan salah satu faktor terbetuknya top of mind. Pengaruh positif tersebut tampak dalam penyataan responden.

H3: waktu penayangan iklan mempunyai pengaruh positif terhadap top of mind sehingga semakin tepat waktu penayangan iklan, maka semakin tinggi top of mind.

Berdasarkan hasil penelitian menunjukkan bahwa waktu penayangan iklan mempengaruhi Top of mind. Menurut Shimp (2000), biaya periklanan, karakteristik khalayak dan kesesuaian pemrograman, sangat bervariasi pada jam-jam tertentu di suatu hari dan hari-hari tertentu di suatu minggu. Apabila waktu penayangan iklan sesuai dengan waktu khalayak sasaran menonton televisi, maka kemungkinan khalayak sasaran melihat iklan produk perusahaan semakin tinggi. Dengan demikian diharapkan khalayak sasaran dapat mengingat iklan yang ditayangkan yang pada akhirnya akan menimbulkan Top of mind. Pengaruh positif ini terlihat pada pernyataan responden.

Dari uraian diatas dapat disimpulkan bahwa ketiga variabel yang diuji yaitu frekuensi penayangan iklan, daya tarik pesan dan waktu penayangan iklan berpenaruh positif terhadap variabel dependennya yaitu top of mind, dengan demikian dapat dikatakan bahwa untuk meningkatkan top of mind, dapat dilakukan dengan meningkatkan faktor-faktor yang mempengaruhinya 
tersebut. Sehingga ketika sudah terjadi top of mind, maka konsumen akan langsung menyebut merek dalam satu kategori produk tertentu. Misalnya ketika diberikan stimulus kata shampo, maka akan langsung mengingat merek shampo Pantene. Jika top of mind tercapai harapannya juga dapat meningkatkan brand awareness yang pada ujungnya akan meningkatkan ekuitas merek keluaran PT Unilever Indonesia, Tbk tersebut.

Berdasarkan analisis kualitatif yang diketahui dari jawaban responden, iklan yang isi pesannya menarik, struktur pesannya mudah dipahami, format pesannya menarik, endorser nya merupakan artis terkenal dan frekuensi penayangan iklannya cukup tinggi serta waktu penayangan iklannya sesuai dengan waktu konsumen menonton televisi akan membuat iklan tersebut diingat oleh konsumen, sehingga dapat meningkatkan puncak kesadaran dalam benak konsumen atau sering di sebut Top of mind. Responden banyak mengingat bintang iklan (endorser) nya adalah Raline Shah dan Anggun C Sasmi sebagai bintang iklan Pantene.

\section{Saran}

Diharapkan penelitian ini dapat menjadi rujukan bagi penelitian selanjutnya yang membahas mengenai top of mind, dan mempertimbangkan variabel- variabel lain sehingga dapat lebih rinci dalam menjelaskan faktorfaktor apa saja yang mempengaruhi top of mind.

\section{DAFTAR PUSTAKA}

Aaker, David, 1996, Building Strong Brands, The Free Press, New York

Bahaudin, T. 2000. Brainware Management: Generasi Kelima Manajemen Manusia. PT Elex Media Komputindo, Jakarta.

Engel et al., 1994, Perilaku Konsumen, Binarupa Aksara, Jakarta

Ghozali, Imam, 2005, Analisis Multivariate dengan Program SPSS, Badan Penerbit Universitas Diponegoro, Semarang

Ihalaw, John J.O.I dan Indriyanti, 2002, Pengulangan Pesan Suatu Iklan dalam Proses Pembelajaran Konsumen, Jurnal Ekobis Dian Ekonomi, Volume 8

Ihalaw, John J.O.I dan Ristiyanti Prasetyo, 2005, Perilaku Konsumen, Penerbit Andi, Yogyakarta

Kotler, 2005, Manajemen Pemasaran, Edisi II, Jilid 2, PT Indeks, Jakarta

Kotler, Philip \& Gerry Armstrong, (2014): Principle Of Marketing, Pearson Pretice Hall, New Jersey

Marketing, 2018, Top Of Brand Award 2018, Edisi Februari 2018

Rudito, Priyantoro, 2007, Membangun Brand Equity Melalui Aktivasi Amygdala Konsumen, Business Review MBA ITB, Volume 2, No. 3 
Simmamora, Bilson, 2003, Membongkar Kotak Hitam Konsumen, PT Gramedia Pustaka Utama, Jakarta

Terence A, Shimp, 2003, Periklanan Promosi, Edisi V, Jilid 1\&2, Erlangga, Jakarta

Tjiptono, Fandy, 2006, Pemasaran Jasa, Bayu Media Publishing, Malang www.marketing.co.id diakses 10 Januari 2018

www.unilever.co.id diakses 12 Januari 2018 